\title{
EFEKTIVITAS RELAKSASI AUTOGENIK TERHADAP KUALITAS TIDUR PASIEN HEMODIALISIS DI RUMAH SAKIT ADVENT BANDUNG
}

\author{
EFFECTIVENESS OF AUTOGENIC RELAXATION ON HEALTH QUALITY OF \\ HEMODIALISIS PATIENTS IN HOSPITAL ADVENT BANDUNG
}

\author{
Imanuel Sri Mei Wulandari', Kusman Ibrahim ${ }^{2}$, Sari Fatimah ${ }^{3}$
}

Keperawatan Medikal Bedah, Fakultas Keperawatan Universitas Padjadjaran Bandung. E-mail: imanuelwulandari@gmail.com

\begin{abstract}
ABSTRAK
Pendahuluan: Gangguan tidur merupakan masalah yang sering dialami oleh pasien Gagal Ginjal Terminal (GGT). Apabila gangguan tidur tidak segera diatasi akan mengakibatkan peningkatan resiko jatuh, penurunan kognitif, bahkan dapat menyebabkan kematian akibat komplikasi dari kardiovaskular. Intervensi mandiri perawat diperlukan untuk mengatasi gangguan tidur, mencegah resiko penyakit kardiovaskular atau komplikasi lainya. Tujuan : penelitian ini bertujuan untuk mengetahui pengaruh relaksasi autogenik terhadap kualitas tidur pasien hemodialisis di RS. Advent Bandung.Metode :Penelitian ini menggunakan quasi eksperiment dengan pendekatan pretest and posttest design with control group. Empat puluh dua pasien dipilih sebagai responden menggunakan consecutive sampling. Responden dibagi menjadi dua kelompok menggunakan jadwal hari terapi, 21 kelompok intervensi dan 21 kelompok kontrol. Kelompok intervensi mendapatkan relaksasi autogenik sebanyak dua kali seminggu selama empat minggu. Kelompok kontrol mendapatkan perawatan standar. Kualitas tidur diukur dengan menggunakan PSQI pada pretest dan postest. Hasil : hasil dari penelitian uji homogenitas berdasarkan karakteristik responden menunjukan tidak berbeda secara signifikan $(p>0,05)$ pada kelompok intervensi dan kontrol. Terdapat perbaikan kualitas tidur secara signifikan pada kelompok intervensi $(p=0,000)$. Dapat disimpulkan bahwa ada pengaruh relaksasi autogenik yang signifikan (memperbaiki) terhadap kualitas tidur pada pasien hemodialisis. Diskusi: hasil penelitian ini bisa menjadi intervensi mandiri perawat dalam memberikan asuhan keperawatan pada pasien hemodialisis.
\end{abstract}

Kata Kunci: hemodialisis, kualitas tidur, relaksasi autogenic

\section{ABSTRACT}

Introduction: Sleeping disorder is one of the common problem among end stage renal disease patients. If sleeping disorder is not well managed, it will lift up the risk of falling, cognitive degradation, even more can cause death due to cardiovascular complication. Independent nurse intervention are required to overcome sleeping disorder, to prevent cardiovascular risk, or other complication. this study is designed to seek for the influence of autogenic relaxation technique to enhance sleeping quality of hemodialysis patient in Bandung adventist hospital. This study was a quasy experimental design with pre and post test design and group control. There were 42 respondents chosen by consecutive sampling. They were divided into two groups base on their homodialysis routine, there were 21 responden each group. Intervention group was taught serial of autogenic relaxation technique twice a week for four weeks. Control group received standard routin. Pre and post Sleeping quality were assesed with PSQI. Autogenic relaxation technique gave a significance better sleeping quality for intervention group which drawn from respondents PSQI score (previous PSQI was nine down to six). Base on the statistical result, the researcher concluded that autogenic relaxation technique gave significant (improve) sleeping quality of hemodialysis patients. The researcher recommends that autogenic relaxation technique considered as independent nursing intervention for hemodialysis patients who are experience sleeping disorder.

\section{SKOLASTIK KEPERAWATAN \\ Vol, 4, No. 1 Januari - Juni 2018}

ISSN: $2443-0935$ E-ISSN 2443 - 1699

Keywords: autogenic relaxation, hemodialysis, sleeping quali 


\section{PENDAHULUAN}

Berdasarkan Riskesdas tahun 2013 tercatat prevalensi penyakit gagal ginjal kronis berdasarkan diagnosis dokter meningkat seiring dengan bertambahnya usia, usia paling banyak adalah $45-54$ tahun yaitu $27 \%$. Sesuai catatan pada Penefri (2011) Diagnosa penyakit utama pasien hemodialisis baru dari data unit hemodialisis yang terkirim adalah GGT sebanyak 87\% (13619 kasus) dengan perbandingan pasien laki-laki lebih tinggi dibanding pasien perempuan. Pernefri (2011) dan Penefri (2013) menunjukan angka bahwa Jawa Barat menduduki urutan pertama dengan pasien yang mendapatkan terapi hemodialisis dengan jumlah 3961 dan jumlah ini meningkat dua kali lipat pada tahun 2013.

Terapi hemodialisis bertujuan untuk memperpanjang harapan hidup pasien dengan GGT, tetapi pasien yang mendapatkan terapi hemodialisis sering mengalami masalah mulai dari masalah fisik sampai masalah psikologi, diantaranya adalah fatigue, depresi dan gangguan tidur (Nasiri, Raei, Vatani \& Khajeh-Kazemi, 2011). Berhubungan dengan terapi hemodialisis yang dijalani oleh pasien, menuntut pasien untuk dapat membatasi cairan yang masuk dan mengontrol diet dengan ketat, menahan rasa sakit saat penusukan jarum, menanggung masalah finansial, dan seringnya menjalani pengobatan dikarenakan oleh penyakit penyerta yang lain. Semua kondisi ini dapat menyebabkan masalah psikologikal dan stres yang memicu pada munculnya gangguan tidur (Hmwe, Subramanian, Tan, \& Chong, 2015).

Kosmadakis dan Medcalf (2008) masalah tidur yang dihadapi oleh pasien yang menjalani terapi HD menunjukan masalah tidur yang paling besar adalah insomnia $(65,9 \%)$, diikuti oleh keluhan RLS/Restless Leg Syndrom (42\%), Obstruksi Sleep Apnea Syndrome/OSAS (31,8\%), keluhan mendengkur (27,3\%), excessive daytime sleepines/EDS (27,3\%), Mengalami Narkolepsi/tidur yang berlebihan $(15,9 \%)$ dan keluhan tidur berjalan/Somnambulisme $(3,4 \%)$.

Banyak faktor dapat menyebabkan pasien yang menjalani terapi HD memiliki masalah terhadap tidur, adanya penumpukan cairan pada pernafasan atas yang mengakibatkan edema dan penyumbatan, kelemahan otot karena uremia dan neuropati, adanya penumpukan karbon dioksida yang dapat menyebabkan hipocarbia kronis, metabolis asidosis dan keracunan uremi (Pedruzzi et al., 2015). Selain hal-hal di atas, ada beberapa faktor yang dapat menyebabkan gangguan tidur pasien dengan HD adalah usia tua, jenis kelamin laki-laki, obesitas, anemia, lamanya waktu dialisis, tingginya tingkat hormon paratiroid (PTH), faktor uremik, perubahan pola sirkadian, kafein, alkohol, dan perubahan tingkat melatonin (Kosmadakis \& Medcalf, 2008; Perlis, Corbit, \& Kloss, 2014).

Terdapat dua jenis terapi yang sering diberikan pada pasien dengan masalah gangguan tidur, yaitu terapi farmakologi dengan pemberian obat tidur (sedativehypnotic) dan terapi nonfarmakologi yang dapat dilakukan dengan memberikan terapi komplementer (Reza et al, 2010). Berman, Snyder, Kozier, dan Erb (2008) juga menambahkan ada beberapa tindakan yang dapat digunakan untuk mengatasi masalah tidur, dengan melakukan aktivitas rutin sebelum tidur (seperti mengganti baju, mematikan lampu), menciptakan lingkungan 
nyaman, menghindari makan berat sebelum tidur dan terapi farmakologi.

Perawat sebagai pemberi asuhan keperawatan dapat melakukan intervensi preventif bagi klien GGT sebagai upaya pencegahan dari komplikasi penyakit dan mampu meningkatkan derajat kesehatan serta kualitas hidupnya (Smeltzer et al., 2010; Potter \& Perry, 2010). Sabet, Naghizadeh, dan Azari (2012) perawat mempunyai tugas dan tanggung jawab untuk melakukan pemeriksaan terhadap masalah yang terjadi pada pasien, dalam kasus ini adalah melakukan evaluasi yang dilakukan secara rutin terhadap masalah tidur pasien HD.

Salah satu terapi komplementer yang mampu mengatasi gangguan tidur akibat masalah fisik dan psikologis pada pasien HD adalah melakukan relaksasi. Relaksasi autogenik merupakan relaksasi yang menggabungan tehnik pernafasan dan meditasi. Proses pernafasan yang tepat dapat meningkatkan asupan oksigen $\left(\mathrm{O}_{2}\right)$ ke dalam tubuh dan meningkatkan suplai $\mathrm{O}_{2}$ ke dalam sel sehingga sel dapat melakukan metabolisme dengan baik untuk menghasilkan energi (Stanley, Leither, \& Sindelir, 2011). Melakukan meditasi mampu berpengaruh terhadap sistem limbik dimana terdapat organ hipotalamus yang mengontrol sistem saraf otonom. Penurunan daerah limbik dapat menjelaskan bagaimana relaksasi mengurangi stres dan meningkatkan stabilitas otonomnya dengan meningkatnya kerja inti hipotalamus yang mengatur sistem saraf parasimpatis (Tang et al (2009); Kox et al (2012); Deepak, Sinha, \& Gusain, 2012).

Yurtkuran, Alp, Yurtkuran, dan Dilek (2007), menyebutkan bahwa karakteristik pasien HD cenderung mengalami fatigue, sehingga kurang memungkinkan untuk diberikan intervensi dengan memberikan latihan gerak yang berat. Diperlukan suatu intervensi yang mampu mencakup fisik dan psikologis yang disesuaikan dengan kemmapuan pasien pada saat melakukan terapi HD. Hasil penelitianya bahwa dengan melakukan meditasi mampu mengatasi masalah nyeri (37\%), fatigue (55\%), masalah tidur (25\%), kekuatan otot (bertambah 15\%), dan intervensi dengan meditasi tidak mempunyai efek samping terhadap pasien HD.

Beberapa penelitian menunjukan pengaruh positif dari relaksasi autogenik. Menurunkan tingkat stres dan heart rate (Lim \& Chin, 2014); mengatasi gejala sakit kepala dan migrain (Zsombok, 2007); meningkatkan kulaitas hidup pasien dengan multiple sclerosis (Sutherland, Anderson \& Morrisi, 2005); mengatasi gangguan pada pasien Irritable Bowel Syndrom (IBS) (Shinozaki et al. 2010); menurunkan gejala insomnia, yaitu depresi dan kecemasan (Bowden, Lorenc, \& Robinson, 2012). Adapun penelitian di Indonesia yang menunjukan manfaat relaksasi autogenik diantaranya adalah menurunkan kecemasan pada ibu primigravida (Farada, 2013); efektif terhadap penurunan kadar gula darah pada pasien Diabetes Melitus (Setyawati, 2010 \& Limbong, Jaya, dan Ariani, 2015); menurunkan depresi pada pasien pre operasi (Muslimin ,2013); dan mengatasi masalah tidur pada pasien post operasi (Supryanto, Istiningtyas, \& Kismanto, 2016).

\section{METODE PENELITIAN}

Penelitian ini menggunakan rancangan Quasi Exeperiment dengan pendekatan Pretest - Postest Control Group Design. Penelitian ini dilakukan, untuk 
mengetahui pengaruh relaksasi autogenik terhadap kualitas tidur pasien GGT yang menjalani HD, dengan melihat nilai kualitas tidur sebelum dan setelah dilakukan relaksasi autogenik. Sampel dalam penelitian ini untuk setiap kelompok (intervensi dan kontrol) adalah 21 orang. Kriteria inklusi pemilihan sampel dalam penelitian ini adalah: Pasien GGT yang melaksanakan HD 2 kali seminggu dengan mempunyai nilai PSQI > 5, usia dewasa, dan mampu berorientasi dengan baik. Adapun kriteria eksklusi adalah pasien yang mempunyai penyakit komorbid, demensia, dan mendapatkan terapi obat tidur. Instrumen dalam penelitian ini terdiri dari instrumen informasi umum pasien, Instrumen Pittsburgh Sleep Quality Index (PSQI), dan Instrumen panduan pelaksanaan relaksasi autogenik.

\section{HASIL PENELITIAN}

Tabel 1. Distribusi frekuensi, persentase dan uji homogenitas karakteristik responden kelompok intervensi dan kelompok kontrol $(n=42)$.

\begin{tabular}{|c|c|c|c|c|}
\hline \multirow{2}{*}{$\begin{array}{c}\text { Karakteristi } \\
k\end{array}$} & Intervensi & \multicolumn{2}{|l|}{ Kantrol } & \multirow{2}{*}{$\begin{array}{c}\text { Nilai } \\
p\end{array}$} \\
\hline & $f(\%)$ & $f(\%)$ & & \\
\hline \multicolumn{5}{|l|}{ Jenis } \\
\hline Kelamin & $12(57,1)$ & $14(66,7)$ & $X=$ & 0,525 \\
\hline Laki-laki & $9(42,9)$ & $7(33,3)$ & 0,37 & \\
\hline Perempuan & & & 6 & \\
\hline Status & & & & \\
\hline Pekerjaan & $7(33,3)$ & $7(33,3)$ & $X=$ & ।,००० \\
\hline $\begin{array}{l}\text { Bekerja } \\
\text { Tidak }\end{array}$ & $14(66,7)$ & $14(66,7)$ & $\begin{array}{c}0,62 \\
8\end{array}$ & b \\
\hline & Mean $\pm S D$ & Mean $\pm S D$ & & \\
\hline $\begin{array}{l}\text { Usia } \\
\text { (tahun) }\end{array}$ & $\begin{array}{c}53,52 \pm 13,6 \\
6\end{array}$ & $53,43 \pm 11,9$ & $\begin{array}{c}t= \\
0,02\end{array}$ & $\underset{\mathrm{c}}{\mathrm{Q}, \mathrm{802}}$ \\
\hline & & $\begin{array}{c}34,8 \mathrm{~B} \pm 24, \\
{[}\end{array}$ & 4 & П \\
\hline $\begin{array}{l}\text { Hemodialis } \\
\text { is (bulan) }\end{array}$ & 8 & & $\begin{array}{l}Z=- \\
0,164\end{array}$ & a \\
\hline
\end{tabular}

Tabel 1. menunjukan data bahwa jenis kelamin pada kedua kelompok didominasi oleh laki-laki yaitu 12 orang $(57,1 \%)$ pada kelompok intervensi dan 14 orang $(66,7 \%)$ pada kelompok kontrol. Sebagian besar responden pada kedua kelompok tidak bekerja dengan presentase $66,7 \%$ atau sebanyak 14 orang di setiap kelompok. Rerata usia pada kelompok intervensi adalah $53,52 \pm 13,66$ dan pada kelompok kontrol $53,43 \pm 11,9$. Adapun rerata lama menjalani terapi hemodialisis pada kelompok intervensi adalah 38,43 bulan dengan standard deviasi 30,8 dan pada kelompok kontrol 34,86 bulan dengan standard deviasi 24,0. Berdasarkan uji homogenitas didapatkan bahwa seluruh karakteristik responden pada penelitian ini homogen atau tidak memiliki perbedaan dengan signifikasi $p$ value > 0,05 .

Tabel 2. Perbedaan Nilai Kualitas Tidur Per Komponen Sebelum dan Setelah Relaksasi Autogenik Berdasarkan Uji Beda Dua Kelompok Berpasangan pada Kelompok Intervensi .

\begin{tabular}{|c|c|c|c|c|c|}
\hline \multirow{3}{*}{$\begin{array}{l}\text { Kualitas } \\
\text { Tidur }\end{array}$} & \multicolumn{5}{|c|}{ Nilai Kualitas Tidur (PSDI) } \\
\hline & \multicolumn{2}{|c|}{ Pretest } & \multicolumn{2}{|c|}{ Postest } & \multirow[t]{2}{*}{ Nilai $p$} \\
\hline & Med & $\begin{array}{l}\text { Min- } \\
\text { Mak }\end{array}$ & Med & $\begin{array}{l}\text { Min- } \\
\text { Mak }\end{array}$ & \\
\hline $\begin{array}{l}\text { Kualitas } \\
\text { Tidur Glabal }\end{array}$ & 马 & $8-10$ & 6 & $4-8$ & 0,००० \\
\hline Komponen & & & & & \\
\hline 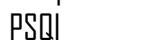 & 1 & $1-2$ & 1 & $0-2$ & 0,008 \\
\hline CI & 2 & $1-2$ & 1 & $1-2$ & 0,005 \\
\hline ¿2 & 2 & $1-2$ & 1 & $1-2$ & 0,001 \\
\hline [3 & 2 & $1-2$ & 1 & $0-1$ & 0,003 \\
\hline$\lceil 4$ & 1 & $1-3$ & 1 & $0-2$ & 0,033 \\
\hline $\begin{array}{l}{[5} \\
{[7}\end{array}$ & 1 & $1-2$ & 1 & $0-1$ & 0,001 \\
\hline
\end{tabular}

Berdasarkan tabel 2. diketahui bahwa nilai kualitas tidur secara global sebelum diberikan terapi relaksasi autogenik pada kelompok intervensi $9(7-10)$ dan setelah diberikan terapi relaksasi autogenik menjadi $6(4-8)$. Hasil dari uji Wilcoxon didapati nilai $\mathrm{p}=0,000(p$ $<0,05)$ pada nilai kualitas tidur secara global, begitu pula dengan nilai $\mathrm{p}$ pada 
setiap subkomponen kualitas tidur menunjukan nilai $p<0,05$ yang bearti ada perbedaan antara sebelum dan setelah diberikan relaksasi autogenik. Hal ini menunjukan adanya pengaruh relaksasi autogenik pada kelompok intervensi. Walaupun secara numerik nilai PSQI mengalami penurunan yang mempunyai arti terjadi peningkatan kualitas tidur, tetapi secara kategorik tetap berada pada kategorik kualitas tidur buruk (PSQI > 5).

Tabel 3. Perbedaan Nilai Kualitas Tidur Per Komponen Sebelum dan Setelah Relaksasi Autogenik Berdasarkan Uji Beda Dua Kelompok Berpasangan pada Kelompok Kontrol.

\begin{tabular}{|c|c|c|c|c|c|}
\hline \multirow{3}{*}{$\begin{array}{c}\text { Kualitas } \\
\text { Tidur }\end{array}$} & \multicolumn{5}{|c|}{ Nilai Kualitas Tidur (PSQI) } \\
\hline & \multicolumn{2}{|c|}{ Pretest } & \multicolumn{2}{|c|}{ Postest } & \multirow{2}{*}{$\begin{array}{c}\text { Nilai } \\
p\end{array}$} \\
\hline & Med & $\begin{array}{l}\text { Min- } \\
\text { Mak }\end{array}$ & Med & $\begin{array}{l}\text { Min- } \\
\text { Mak }\end{array}$ & \\
\hline $\begin{array}{l}\text { Kualitas } \\
\text { Tidur Global }\end{array}$ & 8 & $\begin{array}{l}7- \\
10\end{array}$ & 8 & $5-9$ & 0,070 \\
\hline $\begin{array}{l}\text { Komponen } \\
\text { PSQI }\end{array}$ & & & & & \\
\hline $\mathrm{C} 1$ & 1 & $1-3$ & 1 & $1-3$ & 0,064 \\
\hline $\mathrm{C} 2$ & 2 & $1-2$ & 2 & $1-2$ & 0,317 \\
\hline C3 & 1 & $1-2$ & 1 & $1-2$ & 1,000 \\
\hline $\mathrm{C} 4$ & 2 & $1-2$ & 2 & $0-2$ & 0,317 \\
\hline C5 & 1 & $1-2$ & 1 & $1-2$ & 1,000 \\
\hline C7 & 1 & $1-2$ & 1 & $1-2$ & 0,564 \\
\hline
\end{tabular}

Tabel 3. menunjukan hasil uji statistik Wilcoxon didapatkan nilai kualitas tidur secara global mempunyai nilai $p=0,070$ $(p>0,005)$, begitu juga dengan nilai subkompoenen kualitas tidur ada 5 komponen yang menunjukan angka > 0,05 yang mempunyai arti tidak terdapat perbedaan yang signifikan nilai kualitas tidur pasien hemodialisis pada kelompok kontrol sebelum dan setelah dilakukan relaksasi autogenik.

Tabel 4. Uji Beda Pretest Relaksasi Autogenik pada Pasien Hemodialisis di RS. Advent Bandung.

\begin{tabular}{|c|c|c|c|c|}
\hline \multirow{3}{*}{$\begin{array}{l}\text { Kualitas } \\
\text { Tidur }\end{array}$} & \multicolumn{4}{|c|}{ Nilai Kualitas Tidur (PSQI) } \\
\hline & \multicolumn{2}{|c|}{ Intervensi } & \multicolumn{2}{|c|}{ Kontral } \\
\hline & Med & $\begin{array}{l}\text { Min- } \\
\text { Mak }\end{array}$ & Med & $\begin{array}{l}\text { Min } \\
\text { Ma }\end{array}$ \\
\hline
\end{tabular}

\begin{tabular}{|c|c|c|c|c|c|}
\hline $\begin{array}{l}\text { Kualitas } \\
\text { Tidur Glabal }\end{array}$ & 9 & $8-10$ & 8 & $7-10$ & 0,104 \\
\hline \multicolumn{6}{|l|}{$\begin{array}{l}\text { Kampanen } \\
\text { PSDI }\end{array}$} \\
\hline Cl & 1 & $1-3$ & 1 & $1-3$ & 0,739 \\
\hline [2 & 2 & $1-2$ & 2 & $1-2$ & 0,729 \\
\hline [3 & 2 & $1-3$ & & $1-2$ & 0,054 \\
\hline ᄃ4 & 2 & $1-2$ & 2 & $1-2$ & 0,538 \\
\hline C5 & 1 & $1-3$ & 1 & $1-2$ & 0,495 \\
\hline С7 & 1 & $1-2$ & 1 & $1-2$ & 0,729 \\
\hline
\end{tabular}

Dari tabel 4. dapat dilihat bahwa hasil uji statistik nilai kualitas tidur secara global sebelum relaksasi autogenik didapatkan nilai $p=0,104(p>0,05)$, begitu juga pada subkomponen kualitas tidur mempunyai nilai $p>0,05$, hal ini bearti tidak terdapat perbedaan antara kelompok intervensi dan kelompok kontrol sebelum dilakukan relaksasi autogenik atau mempunyai nilai awal yang sama.

Tabel 5. Uji Beda Postest Relaksasi Autogenik pada Pasien Hemodialisis di RS. Advent Bandung.

\begin{tabular}{|c|c|c|c|c|c|}
\hline \multirow{3}{*}{$\begin{array}{l}\text { Kualitas } \\
\text { Tidur }\end{array}$} & \multicolumn{5}{|c|}{ Nilai Kualitas Tidur (PSQI) } \\
\hline & \multicolumn{2}{|c|}{ Intervensi } & \multicolumn{2}{|c|}{ Kontral } & \multirow[t]{2}{*}{ Nilai $p$} \\
\hline & Med & $\begin{array}{l}\text { Min- } \\
\text { Mak }\end{array}$ & Med & $\begin{array}{l}\text { Min- } \\
\text { Mak }\end{array}$ & \\
\hline $\begin{array}{l}\text { Kualitas } \\
\text { Tidur Global }\end{array}$ & 6 & $4-8$ & 8 & $5-9$ & ०,००० \\
\hline $\begin{array}{l}\text { Komponen } \\
\text { PSDI }\end{array}$ & & & & & \\
\hline CI & 1 & $0-2$ & 1 & $1-3$ & ०,००० \\
\hline [2 & 1 & $1-2$ & 2 & $1-2$ & 0,384 \\
\hline [3 & 1 & $1-2$ & 1 & $1-2$ & 0,158 \\
\hline$\lceil 4$ & 1 & $0-1$ & 2 & 0-2 & 0,003 \\
\hline C5 & 1 & $0-2$ & 1 & $1-2$ & 0,033 \\
\hline C7 & 1 & $0-1$ & 1 & $1-2$ & 0,000 \\
\hline
\end{tabular}

Hasil tabel 5. dapat dilihat bahwa terdapat perbedaan nilai minimal maksimal antara kelompok intervensi dengan kelompok kontrol. Uji statistik nilai kualitas tidur secara global setelah perlakuan didapatkan nilai $p=0,000$ $(p<0,005)$, yang mempunyai arti terdapat perbedaan yang signifikan nilai PSQI sebagai indikator kualiatas tidur pada pasien hemodialisis antara kelompok 
intervensi dan kelompok kontrol. Akan tetapi pada subkomponen kualitas tidur terdapat 2 komponen yang mempunyai nilai tidak terdapat perbedaan antara kelompok intervensi dengan kelompok kontrol, yaitu komponen latensi tidur dan durasi tidur dengan nilai $p>0,05$. Hal ini juga didukung oleh tidak ada perbedaan nilai minimal dan maksimal pada kedua subkomponen tersebut.

\section{PEMBAHASAN}

Berdasarkan hasil tabel 2. diketahui bahwa penelitian ini membuktikan relaksasi autogenik memberikan pengaruh yang positif terhadap kualitas tidur pasien hemodialisis secara subjektif maupun objektif, pada kualitas tidur global memiliki nilai $\mathrm{p}=0,000(\mathrm{p}<$ $0,05)$. Hal ini didukung oleh data yang menunjukan adanya penurunan nilai pada instrumen PSQI yang menunjukan terjadinya peningkatan kualitas tidur pada kelompok intervensi setelah diberikan perlakuan relaksasi autogenik. Selain hal tersebut, hal ini juga didukung dengan adanya data yang menunjukan bahwa hasil dari post test antara kedua kelompok signifikan lebih baik pada kelompok intervensi, data dapat dilihat pada tabel 5 .

Secara umum relaksasi autogenik akan menunjukan hasil yang positif apabila dilakukan secara rutin, perubahan yang terjadi saat relaksasi maupun setelah relaksasi mempengaruhi kerja saraf otonom, relaksasi ini menimbulkan respon emosi dan efek menenangkan, sehingga secara fisiologi sistem saraf dominan simpatis berubah menjadi dominan parasimpatis. Sensasi atau perasaan tenang, ringan dan hangat yang menyebar ke seluruh tubuh merupakan efek yang dapat dirasakan dari relaksasi autogenik (Ismarina, Herliawati, \& Muharyani, 2015). Welz (1991) menjelaskan bahwa perasaan hangat pada ekstrimitas dapat dijelaskan secara fisiologis sebagai vasodilatasi pembuluh darah karena meningkatnya aktivitas sistem saraf parasimpatis, adapun perasaan berat yang terjadi merupakan efek dari ketegangan otot yang menurun. Perpaduan tehnik nafas dalam dan meditasi yang dilakukan pada relaksasi autogenik mampu merangsang pengeluaran neurotransmiter NO (nitride oxide) yang mempengaruhi kerja otot polos untuk menjadi lebih rileks dan vasodilatasi pembuluh darah yang akan mengakibatkan suplai darah ke organ akan meningkat, mampu meningkatkan metabolisme pada sel yang menghasilkan energi sehingga tubuh akan terasa lebih berenergi dan mampu untuk melakukan suatu aktivitas.

Tabel 2. dan tabel 3. menunjukan adanya masalah gangguan tidur pada 6 komponen kualitas tidur pada instrumen PSQI (kualitas tidur secara subjektif, latensi tidur, durasi tidur, efisiensi tidur, ganguan tidur pada malam hari dan gangguan tidur pada siang hari) pada kelompok intervensi dan kontrol. Terdapat 3 komponen yang dominan yaitu latensi tidur dengan nilai 2 yang mempunyai arti pasien mampu memulai tidur antara 31 - 60 menit, durasi tidur dengan nilai 2 yang menujukan durasi tidur pasien hemodialisis anatar 5-6 jam, dan efisiensi tidur juga mendapatkan nilai 2 yang mempunyai arti efisiensi tidur pasien dalam sehari hanya $65-74 \%$. Hasil ini sejalan dengan hasil penelitian yang dilakukan oleh Shariati, et al (2012), dimana keluhan masalah tidur yang sering dikeluhkan pada pasien GGT yang menjalani terapi HD adalah sulitnya mengawali tidur, sulit mempertahankan tidur, sulit untuk kembali tertidur, dan adanya keluhan saat melakukan aktifitas pada siang hari. 
Melihat hasil uji Wilcoxon, terlihat perubahan yang signifikan antara sebelum dan setelah dilakukan relaksasi autogenik pada kelompok intervensi (tabel 2) apabila dibandingkan dengan kelompok kontrol (tabel 3) yang menunjukan tidak adanya perubahan yang bermakna. Hal ini sejalan dengan penelitian Bowden, Lorenc, dan Robinson (2012) dan Supryanto, Istiningtyas, dan Kismanto (2016), bahwa relaksasi autogenik dapat meningkatkan kualitas tidur pasien.

Lamanya menjalani terapi hemodialisis dapat memberi efek terhadap respon psikologi yang berbeda pada setiap pasien, hal ini juga akan mempengaruhi mekanisme koping pada pasien hemodialisis yang berpengaruh terhadap keberhasilan suatu intervensi. Hal ini sejalan dengan penelitian yang dilakukan oleh Armiyati dan Rahayu (2014) yang mengutarakan bahwa ada hubungan antara lama menjalani terapi hemodialisis dengan mekanisme koping ( $p<0,05)$, dengan arah hubungan linear positif yang mempunyai arti semakin lama pasien menjalani terapi hemodialisis semakin adaptif mekanisme kopingnya. Penelitian tersebut terkait dengan proses adaptasi pasien terhadap terapi HD, semakin lama pasien menjalani terapi HD semakin pasien dapat beradaptasi dengan kondisinya dan dapat mengatasi masalah yang ditimbulkan akibat terapi yang dijalaninya. Perawat mempunyai peran untuk memberikan pendidikan kesehatan atau intervensi keperawatan sehingga mekanisme koping pasien semakin membaik.

Terapi komplementer berupa relaksasi autogenik dapat menjadi salah satu alternatif manajemen dalam meningkatkan kualitas tidur secara non farmakologi. Salah satu manfaat dari penggunaan terapi ini dapat mengurangi resiko terjadinya efek samping dari penggunaan obat hypnotic-sedative yang dapat memperberat keluhan insomnia, dengan demikian akan membantu dalam pengurangan cost pasien dan meningkatkan kepuasan pasien terhadap pelayanan keperawatan, serta dapat digunakan untuk mencegah terjadinya komplikasi dari masalahtidur yang tidak teratasi. Perlakuan ini dapat dilakukan sebagai perlakuan mandiri keperawatan atau pun dilakukan secara rutin oleh pasien dan keluarga.

\section{KESIMPULAN}

Kesimpulan dalam penelitian ini adalah relaksasi autogenik memiliki pengaruh positif terhadap kualitas tidur pasien hemodialisis, hal ini ditunjukan dengan menurunya nilai pada instrumen PSQI setelah perlakuan secara signifikan dan bermakna secara statistik ( $p$ value $=$ $0,000)$.

\section{SARAN}

Penelitian ini dapat dijadikan sebagai bahan telaah dan evidence based practice dalam praktek keperawatan medikal bedah terkait manajemen diri untuk mengatasi masalah gangguan tidur. Penelitian ini sebaiknya dilanjutkan dengan menyertakan pengaruh frekuensi hemodialisis terhadap kualitas tidur pada pasien dengan pengukuran kualitas tidur yang berulang (time series), yang dihubungkan dengan tingkat fatigue, kecemasan dan tingkat depresi pada pasien hemodialisis.

\section{DAFTAR PUSTAKA}

Berman, A., Snyder, S. J., Kozier, B., \& Erb, G. (2008). Fundamental of 
nursing: concepts, process, and practice. 8th edition. Philipine: Pearson Education South ASIA PTE.LTD

Blais, K.K., Hayes, J.S., Kozier, B., \& Erb, G. (2012). Praktik keperawatan profesional: konsep \& perspektif. Penerbit Buku Kedokteran : EGC.

British Autogenic Sociaety. (2013). Self generate theraphy for mind and body. www.autogenictheraphy.org.uk

Bowden, A., Lorenc, A., \& Robinson, N. (2012). Autogenic training as a behavioural approach to insomnia: A prospective cohort study. Primary Health Care Research \& Development, 13(2), 175-185.

doi:http://dx.doi.org/10.1017/S1 463423611000181

Buysse, D.J., Reynolds 3rd, C.F., Monk, T.H., Berman, S.R., Kupfer, D.J. (1989). The pittsburgh sleep quality index: a new instrument for psychiatric practice and research. Psyciatry Res 1989:28 (2): 193-213 [Epub 01.05.1989].

Deepak, D., Sinha, A.N., \& Gusain, V.S. (2012). A study on effect of meditation on parasympathetic nervous system functional status in meditation. International Journal of Research in Pharmaceutical and Biomedical Science. ISSN: 2229-3701. Vol.3 (2) Apr - Jun 2012.

Depkes RI. (2013). Riset Kesehatan Dasar. Farada, R. A. (2013). Pengaruh Teknik Relaksasi Autogenik terhadap Tingkat Kecemasan pada Ibu
Primigravida Trimester III di Wilayah Kerja Puskesmas Kotakulon Kabupaten Bondowoso.

Hmwe, N. T. T., Subramanian, P., Tan, L. P., \& Chong, W. K. (2015). The effects of acupressure on depression, anxiety and stress in patients with hemodialysis: A randomized controlled trial. International journal of nursing studies, 52(2), 509-518.

Ismarina, D., Herliawati., dan Muharyani, P.W. (2015). Perbandingan perubahan tekanan darah lansia penderita hipertensi setelah dilakukan terapi musik klasik dan relaksasi autogenik di wilayah kerja puskesmas Palembang. Jurnal Keperawatan Sriwijaya, Volume 2 - Nomor 2, Juli 2015, ISSN No 23555459

Kosmadakis, G.C., \& Medcalf, J.F. (2008). Sleep disorders in dialysis patients. International Journal of Artificial Organ, 31(11),919-927.

Kox, M., Stoffels, M., Smeekens, S.P., Alfen, N.V., Gomes, M., Eijsvogels, T., Hopman, M., Van Der Hoeven, J.G., Netea, M.G., \& Pickkers, P. (2012). The influence of concentration/meditation on autonomic nervous system activity and the innate immune response: a case study. Psychosomatic Medicine, 74:489-494. 0033-31/12/74050489

Lim. S.J., \& Kim. C. (2014). Effects of autogenic training on stress response and heart rate 
variability in nursing students. ASIAN Nursing Research, 286292.

http://dx.doi.org/10.1016/j.anr.2 $\underline{014.06 .003 .}$.

Limbong, M. L., Jaya, R. D., \& Ariani, Y. (2015). Pengaruh Relaksasi Autogenik Terhadap Kadar Glukosa Darah Padapasien Diabetes Melitus Tipe 2. Jurnal Skolastik Keperawatan, 1(01).

MUSLIMIN, A. (2013). Efektivitas Relaksasi Autogenik Untuk Menurunkan Kecemasan Pasien Pre Operasi Kuretase (Doctoral dissertation, Universitas Sebelas Maret).

Nasiri. E., Raei. M., Vatani. J., \& Khajeh-Kazemi. R. (2011). The effect of acupressure of sleep in hemodialysis patients. Journal Medical Science, 11 (5); 236240.

Doi:

10.3923/jms.2011.236.240

Parvan, K., Lakdizaji, S., Roshangar, F., \& Mostofi, M. (2013). Quality of sleep and its relationship to quality of life in hemodialysis patients. Journal of Caring Science, 2(4), 295-304. Retrieved from

http://search.proquest.com/docvi ew/1508688313? accountid=482 $\underline{90}$

Pedruzzi, L., Cardozo, L., Baleprane, J., Stocker-Pinto, M., Monterino, E., Leite, M., \& Mafra, D. (2015). Syatemic inflammation and oxidative stress in hemodialysis patients assosiated with down-regulation of $\mathrm{Nrf} 2$. Journal of Nephrology, 28(4), 495-50.doi:10.1007/s40620-0140162-0

Perlis, M., Corbitt,C., \& Kloss, J. (2014). Insomnia research:3Ps and beyond. Sleep Medicine Reviews, 18(3), 191-193

Pernefri. (2011). 4th Annual Report of Indonesian Renal Registry. Bandung: Indonesian Renal Registry.

Pernefri. (2013). 6th Annual Report of Indonesian Renal Registry. Bandung: Indonesian Renal Registry.

Potter, P.A., \& Perry, A.G. (2010). Fundamental keperawatan : konsep, proses, dan praktik. Edisi 4. Jakarta: EGC

Reza, H., Kian, N., Pouresmail, Z., Masood, K., Bagher, M. S. S., \& Cheraghi, M. A. (2010). The effect of acupressure on quality of sleep in Iranian elderly nursing home residents. Complementary therapies in clinical practice, 16(2), 81-85.

Saunders, S. (2007). Autogenic therapy: Short term therapy for long term gain. British autogenic Society: http://www. autogenic therapy. org. uk.

Sabet, R., Naghizadeh, M.M., \& Azari, Sousan. (2012). Quality of sleep in dialysis pastients. Iranian Journal of Nursing and Midwifery Research. May-June. Vol 17.

Setyawati, A. (2010). Pengaruh relaksasi autogenik terhadap penurunan tekanan darah dan kadar gula 
darah pada pasien DM tipe 2 dengan hipertensi di IRNA Rumah Sakit di Yogyakarta dan Jawa Tengah (Tesis). http://www.lontar.ui.ac.id/file?fi le $=$ digital/137211T\%20Andina\%20Setyawati.pdf.

Shariati, A., Jahani, S., Hooshmand, M., \& Khalili, N. (2012). The effect of acupressure on sleep quality in hemodialysis patients. Complementary Therapies in Medicine. 20, 417-423. doi:http://dx.doi.org/10.1016/j.ct im.2012.08.001

Shinozaki, M., Kanazawa, M., Kano, M., Endo, Y., Nakaya, N., Hongo, M., \& Fukudo, S. (2010). Effect of autogenic training on general improvement in patients with irritable bowel syndrome: a randomized controlled trial. Applied psychophysiology and biofeedback, 35(3), 189-19

Smeltzer, S. C., Bare, B. G., Hinkle, J. L., \& Cheever, K. H. (2010). Brunner \& Suddarth's Textbook of Medical-Surgical Nursing. Philadelphia: Wolters Kluwer Health.

Smyth, C. (2007). The Pittsburgh Sleep Quality Index. (Try This: Best Practices in Nursing Care to Older Adults from The Hartford Institute for Geriatric Nursing). Medsurg Nursing, 12(4), 261263.

Stanley, R., Leither, T.W., \& Sindelir, C. (2011). Benefits of a holistic breathing technique in patients on hemodialysis. Nephrology Nursing Journal, 38(2), 149-153.
Supriyanto,A., Istiningtyas, A., dan Kismanto, J. (2016). Pengaruh Teknik Relaksasi Autogenik terhadap pemenuhan kebutuhan tidur pasien post operasi di ruang teratai RSUD DR. Soehadi Prijonegoro Sragen.

Sutherland, G., Andersen, M. B., \& Morris, T. (2005). Relaxation and health-related quality of life in multiple sclerosis: the example of autogenic training. Journal of behavioral medicine, 28(3), 249256.

Tang, Y., Ma, Y., Fan, Y., Feng, H., Wang, J., Feng, S., Lu, Q., Hu, B., Lin, Y., Li, J., Zhang, Y., Wang, Y., Zhou, L., \& fan, M. (2009. Central and autonomic nervous system interaction is altered by short-term meditation. www.pnas.org/cgi/doi/10.1073/p nas.0904031106.

Welz, KH. (1991). Autogenic training: a practical guide in six easy steps. Woodstock, GA 30188.

WHO. (2005). Preventing Chronic Diseases : a Vital Investment. Yang, B., Xu, J., Xue, Q., Wei, T., Xu, J., Ye, C., ... \& Mao, Z. (2015). Non-pharmacological interventions for improving sleep quality in patients on dialysis: systematic review and metaanalysis. Sleep medicine reviews, 23, 68-82.

Yurtkuran, M., Alp, A., Yurtkuran, M., \& Dilek, K. (2007). A modified yogabased exercise program in hemodialysis patients: A randomized controlled study. Complementary Therapies in 
Medicine, 15(3)(164-171). doi: doi: 10.1016/j.ctim.2006.06.008 